\title{
Upaya Meningkatkan Minat Baca Siswa Kelas VII SMP Negeri 2 Sukasada Tahun Pelajaran 2017/2018 Melalui Gerakan Literasi Sekolah dengan Pocari dan Puding
}

\section{Nyoman Sudiana*}

\author{
SMPN 6 Singaraja
}

\section{A R T I C L E I N F O}

Article history:

Received 01 December 2019

Received in revised form

28 December 2019

Accepted 15 January 2020

Available online 25

February 2020

\section{Kata Kunci:}

literasi, minat baca, pojok

baca asri, perpustakaan

dinding

Keywords:

literacy, interest in reading, beautiful reading corner, wall library

\begin{abstract}
A B S T R A K
Tujuan penelitian ini adalah untuk meningkatkan minat baca siswa yang sangat rendah. Lokasi penelitian ini di SMP Negeri 2 Sukasada Kecamatan Sukasada dengan subjek penelitian siswa kelas VII sebanyak 151 orang. Data dalam penelitian ini diperoleh dengan angket minat baca siswa yang kemudian dilakukan analisis secara kuantitatif. Penelitian ini adalah Penelitian Tindakan Sekolah, yang dilaksanakan dalam dua siklus. Setiap siklus dilakukan berdasar tahapan: (1) menyusun rencana kegiatan, (2) melaksanakan tindakan, (3) observasi, dan (4) refleksi. Berdasarkan hasil observasi awal ditemukan minat siswa dalam membaca masih rendah. Setelah dilakukan tindakan siklus I minat siswa dalam membaca menjadi meningkat dengan rata-rata skor minat baca siswa 84,85 dengan jumlah siswa yang memiliki minat baca tinggi sebanyak 124 (82,12\%) siswa. Hasil tindakan pada siklus II rata-rata skor minat baca siswa meningkat lagi menjadi 93,43 dengan 144 (93,36\%) siswa sudah memiliki minat baca yang tinggi. Presentase ketuntasan minat baca pada siklus II ini telah memenuhi indikator keberhasilan yang ditetapkan sehingga disimpulkan bahwa melalui Gerakan Literasi Sekolah dengan pojok baca asri dan perpustakaan dinding di sekolah dapat meningkatkan minat baca siswa kelas VII SMP Negeri 2 Sukasada Tahun Pelajaran 2017/2018.
\end{abstract}

\section{A B S T R A C T}

The purpose of this study is to increase student interest in reading that is very low. The location of this research is in SMP Negeri 2 Sukasada, Sukasada District, with the research subjects of Grade VII students as many as 151 people. The data in this study were obtained by a student interest in reading questionnaire which was then analyzed quantitatively. This research is a School Action Research, which was carried out in two cycles. Each cycle is carried out based on stages: (1) compiling a plan of activities, (2) carrying out actions, (3) observation, and (4) reflection. Based on the results of preliminary observations found that students' interest in reading is still low. After the first cycle of action, students 'interest in reading increases with an average score of 84.85 students' reading interest with a number of students who have high reading interest of 124 (82.12\%) students. The results of actions in the second cycle the average score of students' reading interest increased again to 93.43 with 144 (93.36\%) students already have a high interest in reading. The percentage of completeness of reading interest in the second cycle has met the success indicators determined so that it was concluded that through the School Literacy Movement with beautiful reading corners and wall libraries in schools can increase reading interest in class VII students of SMP Negeri 2 Sukasada 2017/2018 Academic Year. 


\section{Pendahuluan}

Membaca merupakan jendela dunia. Ungkapan ini secara jelas menggambarkan manfaat membaca, yakni membuka, memperluas wawasan dan pengetahuan individu. Membaca membuat individu dapat meningkatkan kecerdasan, mengakses informasi dan juga memperdalam pengetahuan dalam diri seseorang.

Semakin sering membaca buku, semakin luas pengetahuan yang individu miliki. Sebaliknya, semakin jarang membaca buku, pengetahuan yang individu miliki semakin terbatas. Potensi bangsa Indonesia sangat besar apabila ditinjau dari jumlah penduduknya yang terdiri dari berbagai suku, beraneka ragam budaya dan bahasa yang perlu dilestarikan keberadaannya. Namun, potensi yang sangat besar secara kuantitas itu perlu diimbangi dengan kualitas yang dimiliki. United Nations Development Program (UNDP) pada tahun 2014 melaporkan bahwa Human Development Index (HDI) Indonesia berada pada peringkat 108 dari 187 negara (www.hdr.undp.org). Hal tersebut menunjukan kualitas sumber daya manusia Indonesia berada di tingkat menengah. Salah satu faktor penyebab Indonesia belum menempati posisi atas adalah karena rendahnya kualitas pendidikan. Keadaan tersebut diperburuk dengan masih dominannya budaya tutur daripada budaya baca.

Padahal Somadayo (2011: 7) memaparkan bahwa setiap aspek kehidupan melibatkan kegiatan membaca. Kenyataannya, minat membaca masyarakat khususnya anak sebagai pelajar saat ini masih rendah. Rendahnya minat membaca masyarakat, erat hubungannya dengan tingkat pendidikan di negara tersebut (Galus, 2011). Menurut peraturan Undang-Undang Republik Indonesia Nomor 43 Tahun 2007 tentang Perpustakaan bahwa budaya kegemaran membaca dilakukan melalui keluarga, satuan pendidikan, dan masyarakat dengan kerjasama antara pemerintah dalam upaya peningkatan minat baca, dimana pemerintah bertindak sebagai penanggungjawab utama dan pustakawan melakukan kinerja yang optimal (www.perpusnas.go.id). Pada tahun 2011, UNESCO merilis hasil survei budaya membaca terhadap penduduk di negara-negara ASEAN. Budaya membaca di Indonesia berada pada peringkat paling rendah dengan nilai 0,001 . Artinya, dari sekitar seribu penduduk Indonesia, hanya satu yang memiliki budaya membaca tinggi. Pengembangan minat baca ditingkatkan secara berkesinambungan agar terbentuk masyarakat yang berbudaya membaca (Kartika, 2004: 115). Indonesia mengalami loncatan budaya dari budaya tutur ke budaya menonton, tanpa melalui budaya baca terlebih dulu. Sebagian besar masyarakat Indonesia menggunakan waktu luangnya untuk menonton tv dibanding untuk membaca. Data statistik menunjukkan bahwa jumlah waktu yang dipakai oleh anak-anak Indonesia menonton tv adalah 300 menit/hari. Bandingkan dengan anak-anak di Australia 150 menit/hari, Amerika 100 menit/hari, dan Kanada 60 menit/hari (Dharma, 2012).

Pernyataan tersebut menyatakan bahwa masyarakat Indonesia lebih menyukai menonton dibanding membaca. Mendukung pernyataan tersebut, PBB mengungkapkan bahwa satu surat kabar di Indonesia dibaca oleh 25 orang. Idealnya yang ditoleransikan PBB adalah 10 orang untuk satu surat kabar. Sedangkan untuk buku, 35 judul buku untuk satu juta penduduk (Galus, 2011). Rendahnya minat baca disebabkan oleh beberapa hal diantaranya mahalnya harga buku dan terbatasnya fasilitas perpustakaan yang menyebabkan membaca tidak lagi sebagai sarana pembelajaran dan hiburan bagi masyarakat Indonesia. Masyarakat Indonesia lebih memilih membeli televisi dibanding membeli buku (Triatma, 2016).

Perkembangan minat baca dan kemampuan baca terutama siswa kita memang sangat memprihatinkan. Hal ini disebabkan metode yang diberikan terhadap mahasiswa pada umumnya kurang menarik bahkan tidak menyenangkan. Sebagian besar metode yang ada hanya berorientasi pada hasil bukan pada proses. Rendahnya minat baca mahasiswa menjadikan kebiasaan membaca mahasiswa tersebut yang rendah, dan kebiasaan membaca yang rendah ini menjadikan kemampuan kognitifnya rendah pula. Menurut pengamatan penulis itulah yang sedang terjadi pada mahasiswa sekarang ini, yang kemungkinan itu semua disebabkan karena kebanyakan tidak memiliki buku atau fasilitas perpustakaan yang memadai. Buku pelajaran untuk sekolah dasar dan buku bacaan umum atau khusus tidak terkoleksi secara lengkap. Bahkan, banyak mahasiswa bila diberi tugas tidak mampu menyelesaikannya tepat waktu dan untuk perpustakaan belum memiliki petugas khusus yang mengelola perpustakaan secara efektif dan efesien. Dengan demikian, wajar saja kalau mahasiswa tidak memiliki kebiasaan membaca yang memadai. Persoalan minat baca pada mahasiswa adalah masalah yang klasik. Berbagai upaya terus dilakukan untuk dapat meningkatkan minat baca. Namun pada kenyataannya, minat baca mahasiswa masih begitu rendah (Nurhaidah, 2016).

Minat baca adalah keinginan atau kecenderungan hati yang tinggi (gairah) untuk membaca (Siregar, 2014). Definisi itu sejalan dengan pendapat Darmono yang menyatakan bahwa minat baca merupakan kecenderungan jiwa yang mendorong seseorang berbuat sesuatu terhadap membaca (Darmono: 2001). Rendahnya minat baca menentukan kualitas pendidikan, dimana kualitas pendidikan 
itu menentukan kualitas sumber daya manusia di setiap negara. Padahal, Indonesia akan mendapatkan bonus demografi pada 2030 mendatang. Pada kondisi ini, rata-rata usia penduduk Indonesia berada di usia produktif. Dalam bahasa ekonomi kependudukan, demografi dimaknai sebagai keuntungan ekonomis yang disebabkan oleh semakin besarnya jumlah tabungan dari penduduk produktif. Hal ini dapat memacu investasi dan pertumbuhan ekonomi (Wasisto, 2015). Namun perlu ditegaskan pula bahwa bonus demografi tidak memberikan dampak signifikan jika negara minim investasi sumber daya manusia (human capital investment). Oleh karena itu, bonus demografi juga dapat berubah menjadi gelombang pengangguran massal dan semakin menambah beban anggaran Negara (Nasution, 2019).

Pendidikan Budaya membaca dan menulis (literasi) masyarakat Indonesia masih sangat rendah. Hal ini terbukti dari beberapa hasil survei beberapa lembaga internasional, yang menunjukkan budaya literasi masyarakat Indonesia masih kalah dengan negara lain. Hasil penelitian Progress in Internasional Reading Literacy Study (PIRLS 2011) dan Programme for Internasional Students Assesment (PISA 2009 \& 2012) yang mengukur keterampilan membaca peserta didik, Indonesia menduduki peringkat bawah (Buku Saku Gerakan Literasi Sekolah, 2015). Hal ini diperkuat juga dengan data statistic UNESCO 2012 yang menyebutkan indeks minat baca di Indonesia baru mencapai 0,0001. Artinya setiap 1000 penduduk, hanya satu orang saja yang memiliki minat baca (Petunjuk Teknis Kampung Literasi, 2016)

Kondisi tersebut juga terjadi pada siswa SMP Negeri 2 Sukasada berdasarkan hasil pengamatan saat di sekolah dan hasil tanya jawab terlihat bahwa minat baca siswa masih sangat rendah. selama di sekolah terlihat siswa lebih banyak memanfaatkan waktu istirahat untuk pergi ke kantin atau bermain bersama temannya daripada ke perpustakaan. Hanya beberapa siswa saja yang memanfaatkan waktu istirahat untuk membaca buku di perpustakaan. Hal ini diperkuat dengan data pada catatan pengunjung pada buku tamu perpustakaan,

Berdasarkan masalah diatas, untuk mewujudkan budaya gemar membaca seluruh warga sekolah, mendorong penulis untuk membuat inovasi yang dapat menumbuhkan minat baca pada anak yaitu dengan pengadaan pojok baca asri yang disingkat pocari dengan membuatkan teras-teras baca atau tempat duduk disamping beberapa ruang kelas terutama yang berjauhan dengan ruang perpustakaan. Dikatakan pojok baca asri (pocari) karena pojok baca ini ditata dengan asri, disekitarnya ada taman-taman kelas yang asri dengan udara yang sejuk, pandangan luas sehingga siswa dapat membaca buku-buku yang disediakan dengan nyaman.

Pojok baca asri ini difasilitasi buku-buku bacaan non pelajaran yang dipajang pada perpustakaan dinding untuk mendekatkan buku pada siswa . Keberadaan buku pada perpustakaan dinding dipertanggung jawabkan oleh siswa dikelas masing-masing. Pojok baca asri dan perpustakaan dinding ini diadakan dengan tujuan agar setiap saat siswa biasa memanfaatkan waktu yang diluar jam pelajaran untuk membaca buku non pelajaran tanpa harus ke perpustakaan yang letaknya cukup jauh dari kelas mereka, sebab dekat kelas mereka ada tempat nyaman untuk membaca juga sudah tersedia buku-buku tersebut..

Dari uraian di atas, dapat diidentifikasi permasalahan sebagai berikut; (1) minat baca siswa cenderung rendah; (2) kunjungan siswa kelas VII ke perpustakaan rendah; (3) siswa kesulitan dalam menentukan bahan bacaan; (4) saat jam istirahat siswa lebih banyak memanfaatkan waktunya untuk ke kantin; (5) Letak perpustakaan cukup jauh dari ruang kelas siswa yang bermasalah.

Berdasarkan latar belakang dan identifikasi masalah tersebut, peneliti ingin melakukan tindakan lebih lanjut dengan membuat Penelitian Tindakan Sekolah (PTS) yang berjudul "Upaya Meningkatkan Minat Baca Siswa Kelas VII SMP Negeri 2 Sukasada Tahun Pelajaran 2017/2018 Melalui Gerakan Literasi dengan Pocari dan Puding”, 'Pocari' yang dimaksud disini adalah singkatan dari pojok baca asri, sedangkan 'Puding' merupakan singkatan dari perpustakaan dinding.

Permasalahan yang diangkat pada penelitian ini dibatasi pada upaya meningkatkan minat baca siswa kelas VII SMP Negeri 2 Sukasada Tahun Pelajaran 2017/2018 melalui Gerakan Literasi Sekolah dengan Pojok Baca Asri dan Perpustakaan Dinding.

Berdasarkan latar belakang di atas, maka permasalahan yang akan diangkat dalam penelitian ini adalah : Apakah melalui Gerakan Literasi Sekolah dengan adanya pojok baca asri dan perpustakaan dinding di sekolah dapat meningkatkan minat baca siswa kelas VII SMP Negeri 2 Sukasada?

Sedangkan tujuan dalam penelitian yang akan dilakukan adalah untuk mengetahui seberapa tinggi peningkatan minat baca siswa kelas VII SMP Negeri 2 Sukasada akan terjadi setelah adanya pojok baca asri dan perpustakaan dinding di sekolah.

Ada beberapa manfaat teoritis yang dapat diambil dari hasil penelitian ini diantaranya memandu para pendidik dalam mengembangkan kegiatan-kegiatan inovatif untuk meningkatkan minat membaca siswa dan hasil penelitian ini bisa dijadikan pertimbangan dalam membuat inovasi perbaikan pendidikan.

Manfaat praktisnya bagi siswa adalah; siswa menjadi lebih mudah dalam menemukan bahan bacaan di sekolah terutama bahan bacaan non pelajaran dan menumbuhkan keaktifan siswa dalam 
membaca dan menulis sehingga aktivitas membaca siswa dapat ditingkatkan, sedangkan bagi sekolah; untuk meningkatkan pemberdayaan kecakapan para siswa sehingga mampu bersaing dengan sekolah lain

\section{Metode}

Penelitian ini tergolong Penelitian Tindakan Sekolah (School Action Research) dalam upaya meningkatkan meningkatkan minat baca siswa di sekolah, khususnya siswa kelas VII di SMP Negeri 2 Sukasada melalui gerakan literasi sekolah dengan pojok baca asri dan perpustakaan dinding.

Subjek penelitian pada penelitian ini adalah semua siswa kelas VII SMP Negeri 2 Sukasada pada semester II tahun pelajaran 2017/2018 yang terdiri dari 6 kelas yang berjumlah 151 siswa dengan alasan karena minat baca siswa ini paling rendah. Sedangkan objek penelitian yang ditetapkan adalah pojok baca asri dan perpustakaan dinding di sekolah untuk mengoptimalkan minat baca siswa di sekolah, khususnya siswa kelas VII SMP Negeri 2 Sukasada.

Rancangan penelitian yang digunakan dalam penelitian ini adalah rancangan penelitian 2 siklus seperti gambar 1.

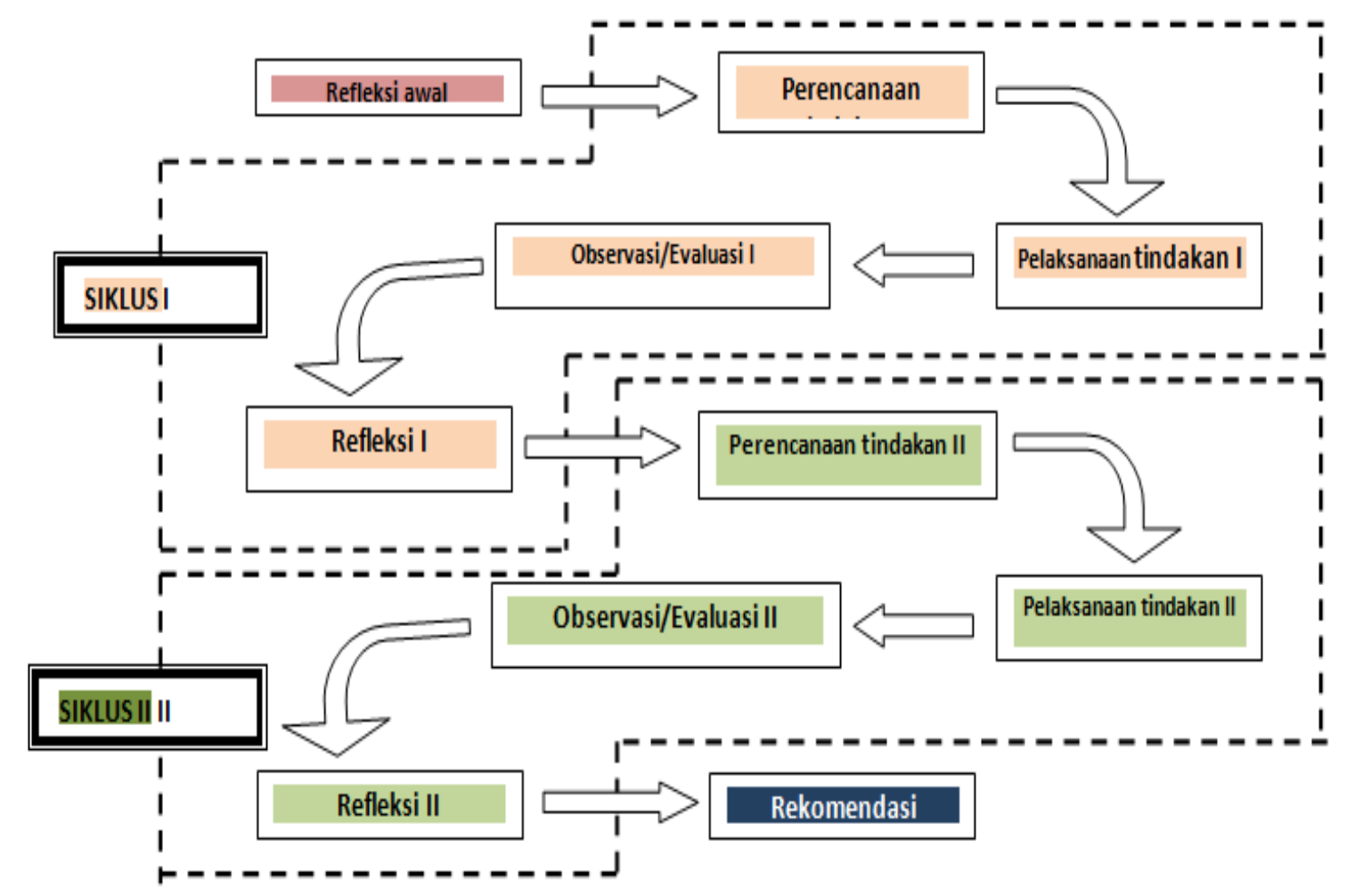

Gambar 1. Alur Pelaksanaan Tindakan Kelas Dua Siklus (Diadaptasi dari Kemmis dan Taggart dalam Sukardi, 2003)

Penelitian dimulai dengan refleksi awal siklus untuk mengetahui kondisi awal sebelum tindakan penelitian dilakukan. Pada tindakan Siklus I dilakukan definisi masalah dilanjutkan dengan pelaksanaan di lapangan, dirumuskan hipotesisnya, dikembangkan hipotesis tersebut, diimplementasikan, dievauasi dari hasil yang didapat dan evaluasi diterapkan. Langkah-langkah pada siklus II sama dengan yang di siklus I yaitu dimulai dengan adanya suatu permasalahan yang baru, didefinisikan masalahnya, dibuat hipotesisnya direvisi, selanjutnya dilakukan implementasi di lapangan, dievaluasi. Demikian berlanjut sampai menemukan hasil yang sesuai tujuan yang direncanakan.

Penelitian tindakan sekolah yang dilakukan ini sudah terjadwal sedemikian rupa yaitu dari bulan Januari s/d Mei 2018.

Dalam penelitian ini, instrumen yang dipakai sebagai pengumpulan data adalah angket/kuisioner minat baca siswa. Kuisioner disusun berdasarkan kisi-isi yang telah dibuat terdiri dari 30 butir pernyataan. Agar tidak membingungkan dan memudahkan siswa menjawab pernyataan dalam instrumen ini semuanya kalimat positif. Data hasil penelitian tindakan sekolah ini dikumpulkan dengan menggunakan lembar observasi/kuesioner minat baca siswa yang diisi oleh siswa pada setiap akhir siklus. 
Sehubungan dengan data yang diperoleh dalam penelitian ini adalah data dalam bentuk angka maka analisis yang digunakan adalah analisis deskriptif kuantitatif. Untuk data kuantitatif dianalisis dengan mencari mean (rata-rata) , median (median) , modus (data yang paling banyak muncul), membuat interval kelas dan melakukan penyajian dalam bentuk tabel dan grafik.

Untuk menentukan minat siswa, dapat dihitung dengan membandingkan rata-rata dengan kriteria Penilaian Acuan Patokan (PAP) skala lima sebagi berikut.

Tabel 1. Kriteria Penggolongan Minat Baca

\begin{tabular}{rc}
\hline Rentang Skor & Kategori \\
\hline $\mathrm{MI}+1,5 \mathrm{SDI} \leq \bar{T}$ & Sangat Tinggi \\
$\mathrm{MI}+0,5 \mathrm{SDI} \leq \bar{T}<\mathrm{MI}+1,5 \mathrm{SDI}$ & Tinggi \\
$\mathrm{MI}-0,5 \mathrm{SDI} \leq \bar{T}<\mathrm{MI}+0,5 \mathrm{SDI}$ & Sedang \\
$\mathrm{MI}-1,5 \mathrm{SDI} \leq \bar{T}<\mathrm{MI}-0,5 \mathrm{SDI}$ & Rendah \\
$\bar{T}<\mathrm{MI}-1,5 \mathrm{SDI}$ & Sangat Rendah \\
\hline
\end{tabular}

Angket yang digunakan dalam penelitian ini terdiri dari 30 item Tiap item mempunyai skor maksimal 4 dan minimal 1. Dengan demikian skor tertinggi ideal dan skor terendah ideal masing-masing adalah 120 dan 30. Sehingga dapat ditentukan mean ideal (MI) dan standar deviasi ideal (SDI) sebagai berikut.

$$
\begin{array}{ll}
\mathrm{Mi} & =1 / 2(120+30) \\
\mathrm{Mi} & =1 / 2(150) \\
\mathrm{Mi} & =75 \\
\mathrm{SDi} & =1 / 6(120-30) \\
\mathrm{SDi} & =1 / 6(90) \\
\mathrm{SDi} & =15
\end{array}
$$

Tabel 2. Pedoman Konversi Skala Lima

\begin{tabular}{cc}
\hline Rata-rata & Kriteria \\
\hline$X \geq 91,5$ & Sangat Tinggi \\
$91,5>X \geq 76,5$ & Tinggi \\
$76,5>X \geq 61,5$ & Sedang \\
$61,5>X \geq 46,5$ & Rendah \\
$X<46,5$ & Sangat Rendah \\
\hline
\end{tabular}

Rata-rata dari skor minat baca siswa yang diperoleh selanjutnya dicocokkan dengan kriteria penggolongan di atas. Dengan demikian akan dapat ditentukan kriteria minat baca siswa terhadap tindakan yang diterapkan.

Sedangkan Kriteria keberhasilan dari penelitian ini adalah terjadi peningkatan rata-rata nilai skor minat baca siswa dari siklus ke siklus dan rata-rata kriteria minat baca siswa terhadap tindakan yang dilaksanakan minimal berkategori tinggi $(X \geq 76,5)$

\section{Hasil dan Pembahasan}

Berdasarkan hasil observasi awal minat siswa dalam membaca masih rendah, bahkan siswa masih sangat jarang ke perpustakaan untuk membaca. Hasil penelitian pada siklus I penelitian adalah; rata-rata minat baca siswa 84,85 yang dikonvesikan ke dalam PAP skala lima, berada pada tingkat membaca 91,5 > X $>76,5$ yang berarti bahwa rata-rata tingkat minat membaca siswa siklus I tergolong tinggi. Ketuntasan klasikalnya 82,12\%, siswa yang belum tuntas 27 orang atau 17,88\% belum mencapai minat baca katagori tinggi.

Sedangkan hasil penelitian pada siklus II adalah; rata-rata minat membaca siswa 93,34 yang dikonversikan ke dalam PAP skala lima, berada pada tingkat membaca X > 91,5 yang berarti bahwa tingkat 
minat baca siswa siklus II tergolong sangat tinggi. Ketuntasan klasikalnya 95,36 \%, siswa yang belum tuntas 7 orang atau $4,64 \%$ belum mencapai minat baca katagori tinggi.

Setelah dilakukan tindakan minat siswa dalam membaca menjadi meningkat dari rata-rata skor minat baca siswa 84,85 pada siklus I menjadi 93,43 pada siklus II dengan kenaikan 8,58 atau 9,2\% dengan jumlah siswa yang memiliki minat baca tinggi sebanyak $124(82,12 \%)$ siswa pada Siklus I dan 144 $(93,36 \%)$ siswa sudah memiliki minat baca yang tinggi pada Siklus. Presentase ketuntasan minat baca pada siklus II ini telah memenuhi indikator keberhasilan yang ditetapkan dengan demikian siklus dinyatakan tidak dilanjutkan dengan kesimpulan bahwa melalui Gerakan Literasi Sekolah dengan adanya pojok baca asri dan perpustakaan dinding di sekolah dapat meningkatkan minat baca siswa kelas VII SMP Negeri 2 Sukasada Semester II Tahun Pelajaran 2017/2018.

\section{Simpulan Dan Saran}

Pemicu rendahnya minat baca siswa adalah kurangnya layanan membaca terhadap siswa, siswa juga jarang pergi ke perpustakaan karena kurang menarik dan bosan serta perpustakaan yang letaknya cukup jauh dari ruang kelas. Kebanyakan siswa hanya memanfaatkan waktu istirahat mereka untuk ke kantin dan kumpul-kumpul bersama temannya. Untuk itu diperlukan pembaharuan yang sifatnya inovatif dan konstruktivis sangat diperlukan. Dalam hal ini peneliti menggunakan pojok baca asri dan perpustakaan dinding sebagai solusi untuk memecahkan permasalahan yang ada. Dari hasil penelitian dan pembahasan dapat disimpulkan bahwa melalui Gerakan Literasi Sekolah dengan pojok baca asri dan perpustakaan dinding dapat meningkatkan minat baca siswa di sekolah, khususnya siswa kelas VII SMP Negeri 2 Sukasada pada Semester Genap Tahun Pelajaran 2017/2018

Sesuai data hasil penelitian,dalam upaya mencapai kualitas yang lebih baik dalam program pendidikan, dapat disampaikan saran-saran sebagai berikut:

1. Bagi guru, agar lebih memotivasi siswa untuk mengunjungi pojok baca asri yang ada, guru juga biasa melakukan perbaikan atau langkah-langkah inovatif terhadap pengembangan pojok baca asri agar lebih baik.

2. Bagi peneliti lain, walaupun penelitian ini sudah dapat membuktikan efek utama dari pengadaan pojok baca asri dalam meningkatkan minat baca siswa, sudah pasti dalam penelitian ini masih ada hal-hal yang belum sempurna dilakukan, oleh karenanya disarankan kepada peneliti lain yang berminat meneliti topik yang sama untuk meneliti bagian-bagian yang tidak sempat diteliti

\section{Daftar Rujukan}

Akhadiah, Sabarti. 1991. Membaca Sebagai Ketrampilan Dasar, Jakarta : Depdikbud.

Dantes, Nyoman. 2012. Metode Penulisan. Yogyakarta: Andi Offset

Direktorat Jendral Pendidikan Dasar dan Menengah, Kementrian Pendidikan dan Kebudayaan Republik Indonesia. 2016. Desain Induk Gerakan Literasi Sekolah, http://dikdas.kemdikbud.go.id/index.php/desain-induk-gls-kemendikbud/, diunduh pada 2 Januari 2018.

KBBI. 2008. Pusat Bahasa DEPDIKNAS. Jakarta.

Nurhaidah. 2016. Dampak Rendahnya Minat Baca Dikalangan Mahasiswa Pgsd Lampeuneurut Banda Aceh Serta Cara Meningkatkannya . Jurnal Pesona Dasar Vol. 3 No.4, Oktober 2016.

Nasution, Anwar Efendi. 2019. E-Kompen (Elektronik-Komik Pendek) Sebagai Solusi Cerdas Dalam Meningkatkan Minat Baca Masyarakat Indonesia Di Era Digital . Jurnal Iqra' Volume 13 No.01 Mei 2019

PISA 2012 Result in Focus: What 15 Year Old Know and What They Can do With What They Know. 2014, https://www.oecd.org/pisa/pisa-2015-results-in-focus.pdf, diunduh pada 10 Januari 2018.

PISA 2015 Result in Focus. 2016, https://www.oecd.org/pisa/keyfindings/pisa-2012-results-overview.pdf, diunduh pada 13 Januari 2018. 
Rachman, Abdulah. 1985. Minat Baca Murid Sekolah Dasar di Jawa Timur. Pusat Pembinaan dan Pengembangan Bahasa. Malang : Depdikbud.

Satgas Gerakan Literasi Sekolah. 2015. Buku Saku Gerakan Literasi Sekolah. Jakarta: Direktorat Jenderal Pendidikan Dasar dan Menengah.

Tim Penyusun Juknis. 2016. Petunjuk Teknis Kampung Literasi. Jakarta: Direktorat Pembinaan Pendidikan Keaksaraan dan Kesetaraan.

Triatma, Ilham Nur. 2016. Minat Baca Pada Siswa Kelas Vi Sekolah Dasar Negeri Delegan 2 Prambanan Sleman Yogyakarta . E-Jurnal Prodi Teknologi Pendidikan Vol. V Nomor 6 Tahun 2016 